\title{
Synergetic effect of microwave blanching and modified atmosphere packaging using laser micro-perforated bags on the storage quality of carrot $* *$
}

\author{
Melvina C. Ezeanaka ${ }^{1,2}$, Min Zhang ${ }^{1,2}$ (1)*, and Yuchuan Wang ${ }^{1}$ \\ ${ }^{1}$ State Key Laboratory of Food Science and Technology, Jiangnan University, 214122 Wuxi, Jiangsu, China \\ ${ }^{2}$ International Joint Laboratory on Food Safety, Jiangnan University, 214122 Wuxi, China
}

Received Feb 6, 2021; accepted Jun 11, 2021

\begin{abstract}
The present study was undertaken to determine the combined effect of microwave blanching and micro-perforated modified atmosphere packaging in maximizing shelf life on the basis of quality attributes which were evaluated during storage. The carrots were blanched in water using a microwave at $360 \mathrm{~W}$ and then stored in micro-perforated modified atmosphere packaging. The results indicated that blanched carrots in micro-perforated modified atmosphere packaging showed an improved storage quality. In particular, it was observed that the firmness of the pretreated samples in the micro-perforated package were significantly improved. The enzyme activity (peroxidase) initially increased and then decreased with longer storage times. There was also a greater reduction in water content in sample C8, probably due to a higher rate of evaporation through the perforations. Water mobility which comprises tightly bound water, loosely bound water, and immobilized water were observed in all samples, while the free water level was insignificant in pretreated micro-perforated samples. The free water, $\mathrm{T}_{24}$ peak was observed for the control sample which increased with increase in storage duration. Also, the effects of this preservation method on other quality parameters such as $\beta$-carotene, water activity, moisture content, and microbial load was limited. However, sample C8 was more effective in retaining quality. Overall, this study demonstrated that blanching carrot in micro-perforated MAP at C8 was the most useful technique in preserving the storage qualities of carrot.

Keyw ords: laser micro-perforated bag, modified atmosphere packaging, blanching, carrot, storage quality
\end{abstract}

*Corresponding author e-mail: min@jiangnan.edu.cn

**This work was financially supported by the National Key R and D Program of China (Contract No. 2018YFD0400801), the 111 Project (BP0719028), Yangzhou City Agricultural Key R\&D Program (No.YZ2019034), the Jiangsu Province (China) "Collaborative Innovation Center for Food Safety and Quality Control” Industry Development Program (2018-2021).

\section{INTRODUCTION}

Fresh food products such as vegetables and fruits are a remarkable source of vital nutrients including micronutrients, vitamins, fibres and various phytochemicals which are essential for human health. In general, due to their high moisture content, fruits and vegetables are highly perishable, hence reduced quality and shelf life are a major challenge for storage purposes and limit the availability of these fresh products (Hussein et al., 2015). Some studies have reported that this reduction in quality and shelf life may occur as a result of continued life processes in fruits and vegetables even after harvest as a result of ongoing metabolic activities such as respiration, ripening and also from presence of mechanical damage and physiological disorders (Irtwange, 2006; Sandhya et al., 2010; Siddiqui, 2011). These underlying causes of deterioration lead to undesirable quality changes in factors such as texture, colour, flavour and beneficial healthy values (Defilippi et al., 2005). Overall, if these factors are not properly controlled, they might eventually lead to reductions in edibility, availability, food losses, and subsequently in financial losses (Defilippi et al., 2005; Fallik, 2004; Irtwange, 2006; Mahajan et al., 2014; Opara et al, 2009; Opara et al., 2012).

(C) 2021 Institute of Agrophysics, Polish Academy of Sciences (c) (1) () $\Theta$ 
Carrots are one of the most preferred root crops because of their high nutrient content such as beta-carotene, dietary fibre, vitamins and minerals as well as their versatility in culinary uses due to their special taste (Gaggiotti et al., 2019). However, carrots are highly susceptible to moisture loss which leads to freshness and quality degradation (Larsen and Wold, 2016). Hence, an effective preservation technique is required to preserve such food products and maintain their quality while extending shelf life to make them readily available even during off seasons. Many food preservation techniques have been applied to date and have in turn been reviewed by many researchers. Chemical based treatments such as antioxidant treatments and washing with ozonized water and sanitizers for food pretreatment are among the preservation techniques which have been effective in the preservation of food products (Beltrán et al., 2005; Garcia et al., 2003; Garcia and Barrett, 2002).

However, consumer awareness concerning food safety and health benefits has resulted in the minimization of the use of these chemicals in the food industry (Hussein et al., 2015). Moreover, research has shown that using these chemical washings and sanitizers cannot guarantee the production of foods free from microbial contamination and without affecting the sensory quality of food products (Martin-Diana et al., 2007). As a result, most of these washing sanitizers and inorganic chemical treatments presently face serious challenges to gain widespread acceptance in the fresh produce industry (Martin-Diana et al., 2007; Worth et al., 2002).

Smart packaging, also referred to as IP (intelligent packaging) is another remarkable innovation primarily designed to track food, sense the internal and external surroundings of the package and is capable of conveying any notable changes to the food manufacturer or producer, hence it effectively monitors the safety status and quality of the food product (Aindongo et al., 2014; Yam et al., 2005). Active packaging is also another recognized innovation which involves the use of emitters and absorbers or a discharging system of active components, ethylene emitters/ scavengers and also moisture absorbers in the packaging material (Rodriguez-Aguilera and Oliveira, 2009). The active ingredients extend shelf-life by modifying the atmosphere surrounding the product inside the package (Jacxsens et al., 2003). However, the extensive use of these intelligent and active packaging methods and their practical application is limited mainly because of regulatory issues and practical limitations including high costs (Realini and Marcos, 2014; Yam et al., 2005). The need for appropriate pretreatment and non-invasive easily available packaging that will prevent desiccation, reduce contamination as well as retaining the appeal of freshness and prolonging shelf life continues to gain more interest in the food industry.

Blanching treatment stabilizes the texture, flavour, colour and nutritional quality content of the product and inactivates enzymes which catalyse deleterious changes.
According to (Terefe et al., 2014) the activity of deteriorative enzymes such as peroxidase (POD), Polyphenol oxidase (PPO), lipase, chlorophyllase, and lipoxygenase (LOX), together with the presence of microorganisms associated with enzymatic activity may be responsible for colour changes, adverse changes in flavour and a reduced shelf life in fresh vegetables and fruit. Some studies have reported that browning discoloration and anthocyanin degradation in lychee fruit correlated to a significant extent with increased POD activity during storage (Zhang et al., 2003; Zhang et al., 2005). (Funamoto et al., 2002; Funamoto et al., 2003) reported that chlorophyll degradation in broccoli correlated with increased POD activity. (Xiao et al., 2017) stated that blanching helps to inactivate both enzymes and microorganisms. Hence, this process maintains quality while extending the shelf life of food (Anthon and Barrett, 2002; Begum and Brewer, 2001; Tunde-Akintunde, 2010). Some researchers have reported on the effects of blanching in various food products. Others have reported on the preferred influence of microwave blanching compared to other blanching methods (Bhattacharya et al., 2017; Bingol et al., 2014; Quarcoo and Manu, 2016; Ruiz-Ojeda and Peñas, 2013; Severini et al., 2016). Moreover, it reduces microbial load and does not affect sensory quality.

The application of various aspects of modified atmosphere packaging (MAP) on different fresh produce has been examined by many researchers. This technique involves the use of gas mixtures to preserve food according to a particular food requirement. Many researchers have also reported on advancements in the use of MAP and its potential to extend shelf-life and preserve the quality of fresh food products (Aindongo et al., 2014; Oms-Oliu et al., 2008; Qu et al., 2020; Sandhya et al., 2010; Soliva-Fortuny and MartinBelloso, 2003). Others have examined the influence of MAP on subsequent outbreaks of foodborne diseases and the growth of resistant foodborne pathogens (Aindongo et al., 2014; Harris et al., 2003). Additionally, MAP is known to be comparatively cheap and easier to use as it does not involve any protocols which have a long duration.

Permeability is one of the factors to be considered when using MAP, which is particularly the case for produce with a high rate of respiration. In some cases, the levels of the components of the packaging atmosphere attained using traditional MAP are not sufficient to maintain quality of produce for a sufficient length of time (Jarvis et al., 2017; Mangaraj et al., 2009; Sandhya et al., 2010). Also, moisture condensation can occur as a result of fluctuating temperatures (Linke and Geyer, 2013). This may lead to the development of undesirable properties such as off-odours and anaerobiosis and can severely modify the volatile profile of packaged food product (Aindongo et al., 2014, Martín-Belloso et al., 2013). Alternatively, the use of a perforated MAP has been proposed as a technique to overcome these limitations (Hussein et al., 2015; Rodriguez-Aguilera and Oliveira, 2009). It is important to note that several 
authors have reported on the use of blanching as a viable pretreatment of fresh food products and also highlighted the use of MAP for extending shelf life. However, as yet, no research has been conducted on the combined effect of blanching and micro-perforated-MAP on carrot storage quality. This research aims to evaluate the synergetic effect of microwave blanching and micro-perforated MAP on carrot quality during storage.

\section{MATERIALS AND METHODS}

Fresh carrots (Daucus carota ) were purchased from Auchan supermarket (Wuxi, China), at the full ripeness stage. The carrots were refrigerated at $4^{\circ} \mathrm{C}$, less than 24 hours prior to processing.

The carrots were first washed, peeled and finally sliced into 8-mm pieces before being blanched in water at $360 \mathrm{~W}$ for 300 secs using a microwave oven (Panasonic Co., Ltd, China) with a maximum rated power of $800 \mathrm{~W}$ at $2450 \mathrm{MHz}$. The internal dimensions of the microwave oven were approximately $302 \times 509 \times 348 \mathrm{~mm}$ (Başkaya et al., 2015). The actual microwave power level was $669 \mathrm{~W}$ using the IMPI-2L method (Saifullah et al., 2019). For the experiment, $100 \mathrm{~g}$ of carrot slices was blanched and cooled immediately in ice. Afterwards, the surface water was removed using a water removal machine (Shandong Duckling Group Home Appliance Co. LTD China, Model T 68-188 dehydrator) at $50 \mathrm{~W}$ for $2 \mathrm{~min}$.

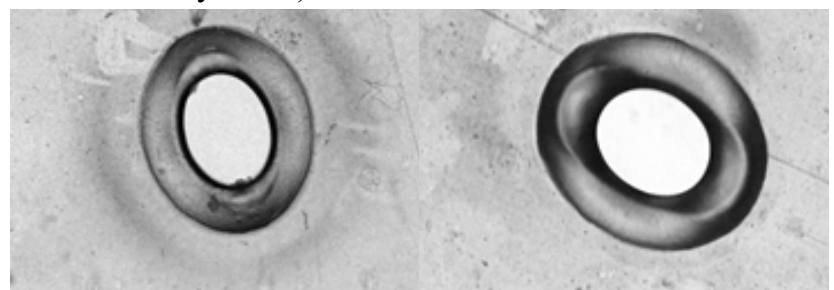

a)

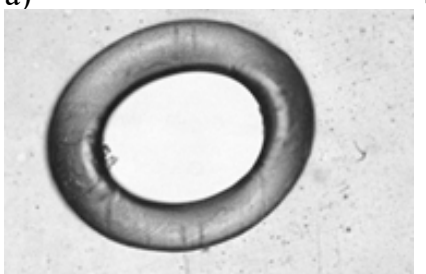

b)

c)

Fig. 1. Microscopic view laser micro-perforation (a) $0.05 \mu \mathrm{m}$, (b) $0.10 \mu \mathrm{m}$, (c) $0.15 \mu \mathrm{m}$.

The samples were placed in high density polyethylene (HDPE) $16 \times 23 \times 8 \mathrm{~cm}$ packaging film, and then sealed in an atmosphere of $5 \% \mathrm{O}_{2}, 10 \% \mathrm{CO}_{2}, 85 \% \mathrm{~N}_{2}$ using a modified atmosphere multifunctional machine (Hengzhong Machinery Co., Zhangjiagang, China). Perforation was accomplished using a laser machine (Wuxi Yiwang Laser device, China) producing holes of various sizes, $0.05 \mu \mathrm{m}$, $0.10 \mu \mathrm{m}$, and $0.15 \mu \mathrm{m}$. The number of perforations were maintained within the range of 4 to 8 for each perforation size. The samples were identified according to their per- foration sizes, $0.05 \mu \mathrm{m}$ (B8), $0.10 \mu \mathrm{m}$ (C4 and C8) and $0.15 \mu \mathrm{m}$ (D4 and D8), making up 5 samples altogether. A light microscope was used to measure the perforation sizes at 100 times magnification as shown in Fig. 1. The carrot were stored at $4^{\circ} \mathrm{C}$ for 30 days. The samples were analysed at 5-day time intervals $(0,5,10,15,20,25$, and 30 days). All the analyses were carried out in triplicate.

The firmness of the sliced carrots was measured using a texture analyser (TA-XT2i, UK) according to the method of (Fan et al, 2019). The measurement was carried out at a pretest speed of $2.00 \mathrm{~mm} \mathrm{~s}^{-1}$, and the test speed and posttest speed were determined at a penetration distance of $10 \mathrm{~mm}$ to determine the maximum force $(\mathrm{N})$.

The carotene content was determined as described (Başkaya Sezer and Demirdöven, 2015). The samples were extracted using a mixture of (acetone: hexane: ethanol, 25: 50: $25, \mathrm{v} / \mathrm{v} / \mathrm{v}$ ). $2 \mathrm{~g}$ of carrot samples were homogenized with $38 \mathrm{ml}$ of the mixture using a lab blender for 20 secs, which was then centrifuged at $5320 \mathrm{rcf}$ for $12 \mathrm{~min}$ at $5^{\circ} \mathrm{C}$. The absorbance was determined using a spectrophotometer (Kyoto Shimadzu Co., Ltd, Japan) at $450 \mathrm{~nm}$. The $\beta$-carotene content was determined in terms of milligram per kilogram.

The moisture content of the carrot samples was evaluated at a constant temperature of $105^{\circ} \mathrm{C}$ using a hot air oven. The sample was oven-dried until a constant weight was achieved according to the method of (AOAC 2000).

The water activity of the carrot samples was determined using a laboratory water activity analyser (Lab Master, S/N: $1612 \mathrm{o} 16)$ at $25^{\circ} \mathrm{C}$. The carrot samples were placed in a sample chamber after calibration until equilibrium was reached.

Low field nuclear magnetic resonance (LF-NMR) was used to analyse the transverse relaxation time $\left(\mathrm{T}_{2}\right)$ of carrot as presented by (Fan et al., 2019) using an analyser (MiceoMR20-030V-1, Numag Electric Co., Suzhou, China) with a resonance frequency of $23.2 \mathrm{MHz}$ and a $0.5 \mathrm{~T}$ magnetic field intensity. The operating temperature of the magnet was $32^{\circ} \mathrm{C}$. First, the oil sample was calibrated and free induction decay (FID) was used to adjust the centre frequency. Next, the $T_{2}$ relaxation time and pulse parameters: $\mathrm{NECH}$ (number of echoes) $=15,000, \mathrm{NS}$ (number of scans) $=4$, TD $($ sampling points $)=750,002$, TW (time waiting $)=$ $6000 \mathrm{~ms}, \mathrm{P} 2$ (pulse time of $180^{\circ}$ ) $=11 \mu \mathrm{s}, \mathrm{P} 1$ (pulse time of $\left.90^{\circ}\right)=6 \mu \mathrm{s}, \mathrm{TE}($ time echo $)=0.5 \mathrm{~ms}, \mathrm{O}($ Offset frequency $)=$ $494824.07 \mathrm{kHz}$, SW (sampling frequency) $=100 \mathrm{kHz}$, were evaluated automatically using the Carr-Purcell-MeiboomGill pulse sequence (CPMG).

Crude enzyme extract was prepared according to a method described by previous researchers (Morales-Blancas et al., 2002). One hundred $\mathrm{ml}$ of potassium phosphate buffer $\left(0.1 \mathrm{~mol} \mathrm{~L}^{-1}, \mathrm{pH} 6.5\right)$ was used to homogenize $40 \mathrm{~g}$ of carrot sample and then centrifuged for $40 \mathrm{~min}$ at $9,000 \mathrm{rpm}$ at $4^{\circ} \mathrm{C}$. The POD was determined using the collected enzyme extract. The POD substrate solution was prepared using a mixture of $99.8 \mathrm{~mL}$ potassium phosphate buffer, $0.1 \mathrm{~mL}$ hydrogen peroxide $(30 \%)$, and $0.1 \mathrm{~mL}$ of guaiacol. After 
a few minutes of shaking, the POD was assayed using a mixture of $3.48 \mathrm{~mL}$ of substrate and $0.12 \mathrm{~mL}$ of enzyme extract. Measurements were carried out at $470 \mathrm{~nm}$ based on the increase in absorbance. One unit of enzyme activity was assumed to occur with a change of 0.01 absorbance units per min for POD.

The colour properties of the stored carrot samples were analysed using a laboratory Colour Reader, more specifically the CR-400 Chroma Meter (Konica Minolta Sensing Inc., Osaka, Japan). Initially, before the colour analysis was performed, the instrument was calibrated using a standard white porcelain plate. The $\mathrm{L}^{*} \mathrm{a}^{*} \mathrm{~b}^{*}$ parameters were considered in order to evaluate the colour change in carrot. $\mathrm{L}^{*}$ indicates the lightness value, $a^{*}$ indicates redness, while $b^{*}$ indicates the yellowness value. To determine the average of the $\mathrm{L}^{*} \mathrm{a} * \mathrm{~b}$ values, the carrot slices were scanned at three different places.

The total plate count of the carrot samples was determined according to the method (Fan et al., 2019). This was accomplished by homogenizing $1 \mathrm{~g}$ of carrot with $9 \mathrm{~mL}$ of saline solution. The solution was diluted, and then $1 \mathrm{~mL}$ was added to a petri dish with nutrient agar and incubated for $48 \mathrm{~h}$ at $37^{\circ} \mathrm{C}$. The results were expressed in terms of the colony-forming unit per milligram $\left(\mathrm{CFU} \mathrm{m}{ }^{-1}\right)$ of sample.

Analysis of data was carried out using a non-linear regression technique (Graph Pad PRISM ${ }^{\circledR}$ Version 8.0.2.263 software). A one-way ANOVA was performed and the multiple comparisons data were corrected using Tukey's statistical hypothesis testing.

\section{RESULTS AND DISCUSSION}

A loss of firmness was not observed within 10 days of the initiation of the storage period. Initially, the firmness of the carrot increased for up to 10 days and then decreased (Fig. 2).
The increase during the first 10 days of storage could be attributed to moisture migration from the product. (Dawange et al., 2016) reported an increase in the firmness of the perforated carrot samples as a result of moisture loss causing dryness in the product. (Klaiber et al., 2005) also reported an increase in the firmness of sliced carrot due to a loss of moisture. However, (Dawange et al., 2016) reported that carrot stored under perforated MAP decreased in firmness within 8 days of the initiation of storage due to the natural ageing of the vegetable. Therefore, the decrease in firmness after 10 days could be ascribed to the natural ageing of the carrot samples.

Based on the initial beta carotene content of carrot, (Kaack et al., 2001) observed that seasonal variation can affect beta carotene content. The authors reported a higher beta carotene content in carrot for warm and sunny years. The authors also reported that the application of nitrogenous fertilizer at a rate of about $25 \mathrm{~kg} \mathrm{~km}^{-2}$ in the summer season can increase the beta carotene content of carrot. Blanching also increases the carotene content of carrot. This may occur as a result of the loss of moisture and soluble solids during the blanching process which includes the phenomenon of greater chemical extractability (Dutta et al., 2005). Dutta et al. (2005) reported that after blanching carrot for 3 minutes, the carotene content increased by $65 \%$. Also, the inactivation of certain oxidative enzymes during blanching may cause a further breakdown of some structures which leads to the higher bio-availability of beta carotene (Dutta et al., 2005; Guerra-Vargas et al., 2001). During the 30-day storage period, the B-carotene content of the pretreated carrot samples decreased from an initial value of $8.484 \mathrm{mg} \mathrm{kg}^{-1}$ to $6.591 \mathrm{mg} \mathrm{kg}^{-1}$ (C8), $6.074 \mathrm{mg} \mathrm{kg}^{-1}$ (D8), $5.764 \mathrm{mg} \mathrm{kg}^{-1}$ (D4), $5.068 \mathrm{mg} \mathrm{kg}^{-1}$ (C4), $4.3884 \mathrm{mg} \mathrm{kg}^{-1}$
A

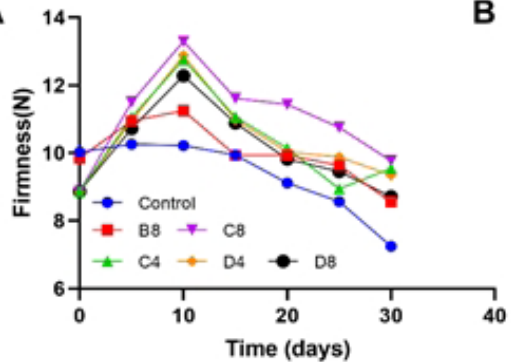

B

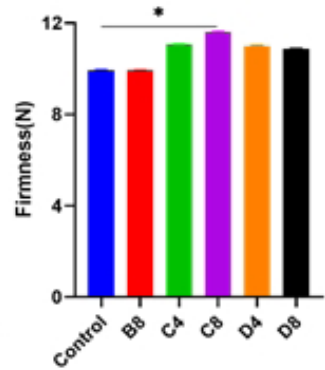

C

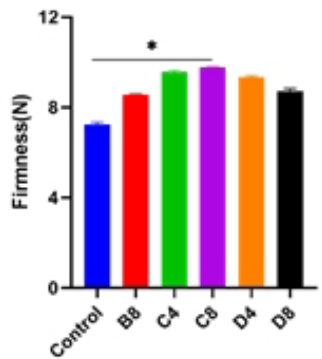

Fig. 2. Effect of blanching and micro-perforated MAP on the firmness of carrot (A) for 30 days of storage (B) comparative analysis at 15 days and (C) 30-days of storage.
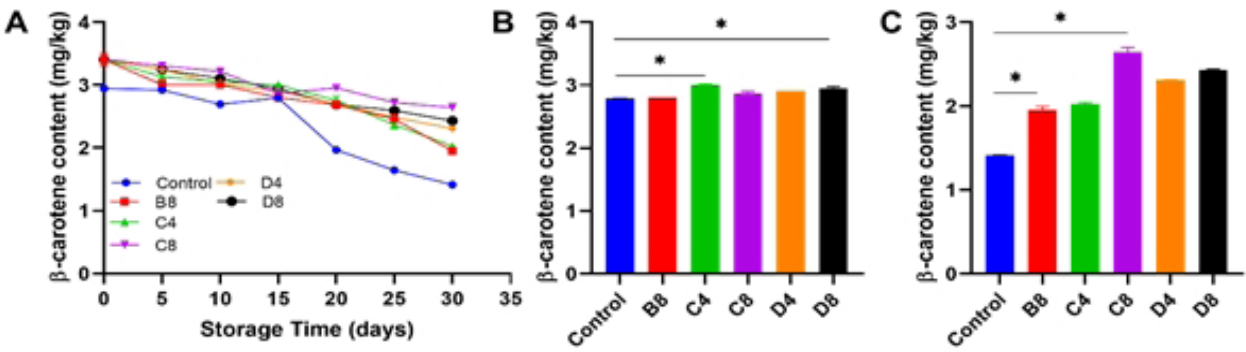

Fig. 3. Effect of blanching and micro-perforated MAP on the $\beta$-carotene of carrot (A) for 30 days of storage, (B) comparative analysis at 15 days and (C) 30-days of storage. 
A

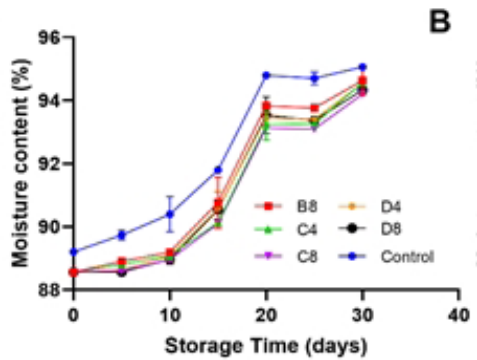

B

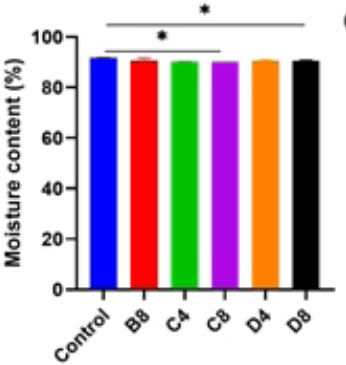

C

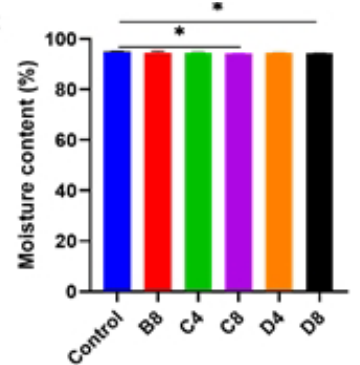

Fig. 4. Effect of blanching and micro-perforated MAP on the moisture content of carrot (A) for 30 days of storage, (B) comparative analysis at 15 days and (C) 30-days of storage.
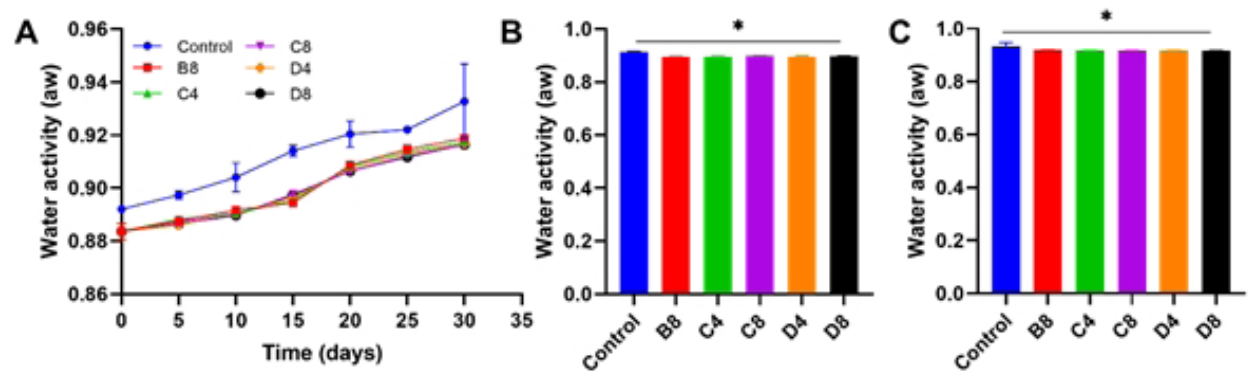

Fig. 5. Effect of blanching and micro-perforated MAP on the water activity of carrot (A) for 30 days of storage, (B) comparative analysis at 15 days and (C) 30-days of storage.

(B8), and from $7.343 \mathrm{mg} \mathrm{kg}^{-1}$ to $3.555 \mathrm{mg} \mathrm{kg}^{-1}$ for the control sample respectively (Fig. 3). The results show that the decrease was greater for the control sample as compared to the pretreated samples stored in micro-perforated MAP. (Dawange et al., 2016) observed a decrease in $\beta$-carotene for all of the perforated packaged samples and control samples after the initiation of storage from the initial value of $9.512( \pm 0.9)$, and reported that the decrease was greater in the control samples by more than 4\%. (Howard and Dewi, 1996) reported a decrease in the $\beta$-carotene concentration of processed carrots stored at $1^{\circ} \mathrm{C}$ and $2^{\circ} \mathrm{C}$ from 57.2 to $47.3 \mathrm{ppm}$ after 17 days of storage. (Ilić et al., 2013) also observed similar results for carrot samples stored for 180 days at $0-2^{\circ} \mathrm{C}$ and $<90 \% \mathrm{RH}$.

Figs 4 and 5 show the moisture content and water activity of the carrot samples respectively. The results demonstrate that both the moisture content and water activity increased with duration of storage. This may be the result of the migration of water vapour from the storage environment into the packaging material. According to research carried out by (Wani and Kumar, 2018), there was an increase in the moisture content of oat and fenugreek during storage due to the migration of water vapour into the packaging material from the storage material and also HDPE permeability. (Hossain and Gottschalk, 2009) reported an increase in moisture content as a result of increases in the air permeability of the polyethylene bag. Initially the moisture content for the control and $360 \mathrm{~W}$ was $89.2 \%$ and $88.6 \%$ respectively, which increased to $94.2 \%$ for $\mathrm{C} 8,94.3 \%$ for $\mathrm{D} 8,94.5 \%$ for D4, $94.5 \%$ for $\mathrm{C} 4,94.6 \%$ for B 8 and $95.1 \%$ for the control respectively. Similarly, the water activity of the control sam- ple was greater than that of the pretreated sample throughout the storage period, with $\mathrm{C} 8$ having the lowest value. A similar result was observed by (Kumar et al., 2012), who reported an increase in the water content of carrot, rice, and pulse flour due to water migration from the environment.

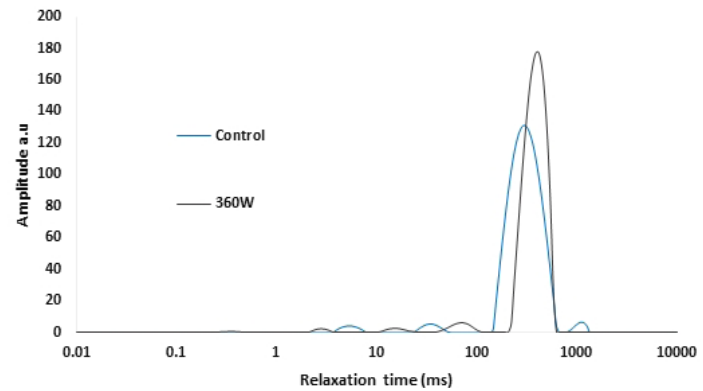

Fig. 6. Transverse relaxation times $\left(\mathrm{T}_{2}\right)$ in carrot for (a) control, (b) carrot pretreated at $360 \mathrm{~W}$ before storage in micro-perforated MAP

LF-NMR was used to monitor the water status of the carrot samples during storage. (Ezeanaka et al., 2019) reported that LF-NMR may be applied to study the states and mobility of water in food products through the observed relaxation time by accurately measuring the radio resonance frequency absorption by non-zero nuclear spins $(\operatorname{spin} 1 / 2)$ from protons in an external static magnetic field. According to (Zang et al., 2017), the $\mathrm{T}_{2}$ relaxation time depends on water mobility. The varying binding ability of macromolecules and water molecules has a significant impact on the relaxation rate, showing various water binding states. The longer the relaxation time $T_{2}$, the greater the mobility of the water and vice versa. Fig. 6 shows the water status of 

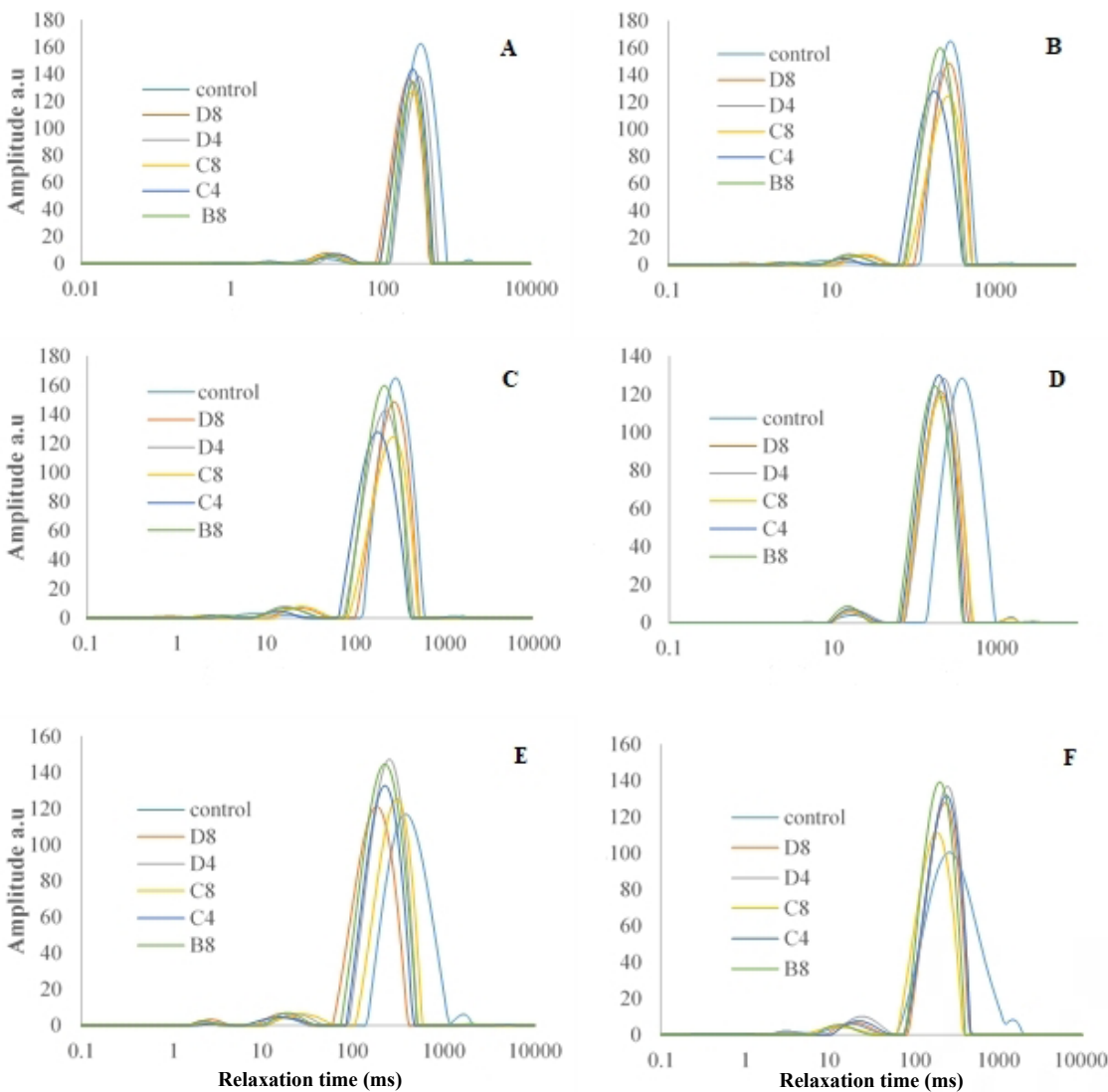

Fig. 7. Transverse relaxation times $\left(\mathrm{T}_{2}\right)$ in carrot for (A) 5 days, (B) 10 days, (C) 15 days, (D) 20 days, (E) 25 days, (F) 30 days of storage in micro-perforated MAP.

the carrot samples before storage while Fig. 7 portrays the water status of the carrot samples during 30 days storage. Initially, the relaxation times for three peaks were observed. The shortest relaxation time $T_{21}$ with a range of $0.1-10 \mathrm{~ms}$ is considered to be caused by tightly bound water. $T_{22}$, with a range of 10-100 ms represents the lightly bound water, while $\mathrm{T}_{23}$ with a range of $10-100 \mathrm{~ms}$ is the most prominent portion and represents the immobilized water. With longer periods of storage time, the $4^{\text {th }}$ peak of $\mathrm{T}_{24}$ was observed in the control sample at a range of 1000-10000 ms, which is thought to originate from free water. The result demonstrated that the $T_{21}$ value did not change significantly $(p \leq 0.05)$ throughout the storage period. This is probably due to the fact that it is closely related to internal structure and relatively stable (Aindongo et al., 2014). At first, $\mathrm{T}_{22}$ and $\mathrm{T}_{23}$

increased, however, this was followed by a decrease as the storage duration lengthened. $\mathrm{T}_{23}$ of the $\mathrm{C} 8$ sample was lower compared to the other pretreated samples while that of the control presented the highest value. This is thought to be the result of a decrease in the metabolic rate. The appearance of $\mathrm{T}_{24}$ in the control samples which increased with the duration of storage shows relative increases in the metabolic rate and probably in membrane permeability as well.

Blanching is an effective pretreatment for inhibiting enzyme activity. Lamikanra (2002) reported that enzyme activity continues if they are not destroyed, which can lead to the formation of an off-colour and off-odour as well as colour changes. However, (Bedford and Joslyn, 1939) research has shown that completely inactivating peroxidase is not necessary to avoid off-flavours and off-colours in foods even
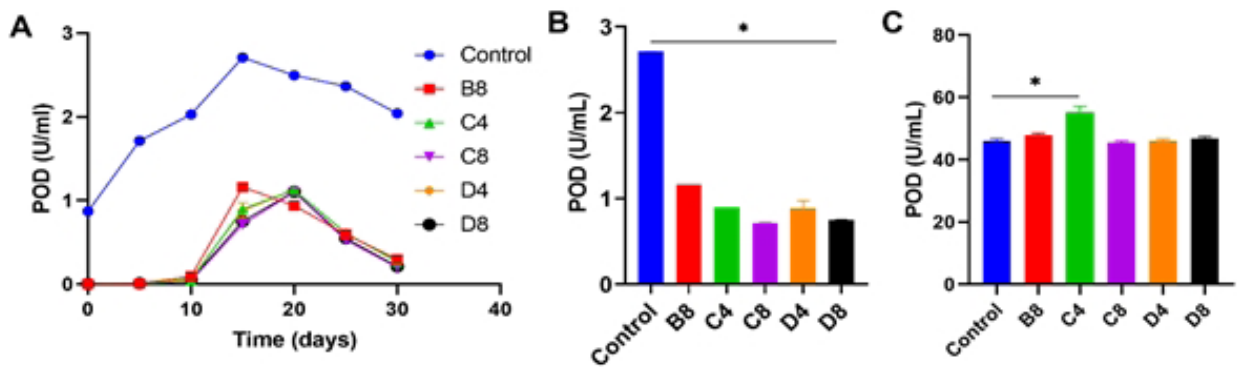

Fig. 8. Effect of blanching and micro-perforated MAP on the peroxidase (POD) of carrot (A) for 30 days of storage (B) comparative analysis at 15 days and (C) 30 days of storage. 
Table 1. Colour analysis L* of blanched carrot in micro-perforated MAP for 30 days of storage

\begin{tabular}{ccccccc}
\hline \multirow{2}{*}{ Days } & \multicolumn{7}{c}{ Treatments } \\
\cline { 2 - 7 } & Control & B8 & C4 & C8 & D4 & D 8 \\
\hline 0 & $52.28 \pm 3.12 \mathrm{a}$ & $45.05 \pm 2.61 \mathrm{~b}$ & $45.05 \pm 2.61 \mathrm{~b}$ & $45.05 \pm 2.61 \mathrm{~b}$ & $45.05 \pm 2.61 \mathrm{~b}$ & $45.05 \pm 2.61 \mathrm{~b}$ \\
5 & $54.02 \pm 1.59 \mathrm{a}$ & $46.96 \pm 1.15 \mathrm{~b}$ & $45.01 \pm 1.99 \mathrm{~b}$ & $46.29 \pm 2.39 \mathrm{~b}$ & $45.46 \pm 0.86 \mathrm{~b}$ & $47.08 \pm 0.76 \mathrm{~b}$ \\
10 & $51.62 \pm 1.84 \mathrm{a}$ & $44.90 \pm 0.365 \mathrm{~b}$ & $46.22 \pm 0.79 \mathrm{~b}$ & $45.90 \pm 1.30 \mathrm{~b}$ & $45.70 \pm 0.38 \mathrm{~b}$ & $44.66 \pm 0.46 \mathrm{~b}$ \\
15 & $52.50 \pm 1.18 \mathrm{a}$ & $46.82 \pm 2.855 \mathrm{bc}$ & $46.37 \pm 0.19 \mathrm{bc}$ & $47.56 \pm 1.45 \mathrm{~b}$ & $47.99 \pm 0.77 \mathrm{~b}$ & $48.86 \pm 0.86 \mathrm{ab}$ \\
20 & $54.48 \pm 1.44 \mathrm{a}$ & $46.86 \pm 0.14 \mathrm{~b}$ & $46.76 \pm 0.25 \mathrm{~b}$ & $46.58 \pm 2.39 \mathrm{~b}$ & $45.66 \pm 0.63 \mathrm{~b}$ & $46.09 \pm 0.34 \mathrm{~b}$ \\
25 & $54.22 \pm 2.31 \mathrm{a}$ & $47.49 \pm 0.36 \mathrm{~b}$ & $45.59 \pm 1.86 \mathrm{bc}$ & $46.32 \pm 2.18 \mathrm{bc}$ & $45.29 \pm 1.07 \mathrm{bc}$ & $45.35 \pm 0.25 \mathrm{bc}$ \\
30 & $55.23 \pm 2.61 \mathrm{a}$ & $45.53 \pm 0.30 \mathrm{~b}$ & $45.99 \pm 0.35 \mathrm{~b}$ & $46.81 \pm 1.09 \mathrm{~b}$ & $47.95 \pm 0.41 \mathrm{~b}$ & $46.02 \pm 0.99 \mathrm{~b}$ \\
\hline
\end{tabular}

Values represent "Mean \pm SD" of triplicate readings. Values followed by different letters in the same column are significantly different at $\mathrm{p} \leq 0.05$.

Table 2. Colour analysis a* of blanched carrot in micro-perforated MAP for 30 days of storage

\begin{tabular}{ccccccc}
\hline \multirow{2}{*}{ Days } & \multicolumn{5}{c}{ Treatments } \\
\cline { 2 - 7 } & Control & B8 & C4 & C8 & D4 & D8 \\
\hline 0 & $19.44 \pm 1.17 \mathrm{~b}$ & $21.23 \pm 0.53 \mathrm{ab}$ & $21.23 \pm 0.53 \mathrm{ab}$ & $21.23 \pm 0.53 \mathrm{ab}$ & $21.23 \pm 0.53 \mathrm{ab}$ & $21.23 \pm 0.53 \mathrm{ab}$ \\
5 & $19.71 \pm 0.83 \mathrm{c}$ & $21.44 \pm 1.60 \mathrm{ab}$ & $21.07 \pm 0.25 \mathrm{bc}$ & $21.14 \pm 0.28 \mathrm{bc}$ & $21.78 \pm 0.83 \mathrm{ab}$ & $22.42 \pm 1.03 \mathrm{a}$ \\
10 & $20.36 \pm 0.22 \mathrm{c}$ & $21.00 \pm 0.42 \mathrm{bc}$ & $24.14 \pm 1.45 \mathrm{ab}$ & $24.52 \pm 1.91 \mathrm{a}$ & $22.53 \pm 0.39 \mathrm{~b}$ & $24.97 \pm 0.75 \mathrm{a}$ \\
15 & $22.32 \pm 0.60 \mathrm{c}$ & $21.93 \pm 0.47 \mathrm{bc}$ & $24.85 \pm 2.41 \mathrm{a}$ & $25.68 \pm 2.13 \mathrm{a}$ & $24.83 \pm 0.27 \mathrm{ab}$ & $25.15 \pm 1.23 \mathrm{ab}$ \\
20 & $24.21 \pm 2.19 \mathrm{ab}$ & $25.18 \pm 0.14 \mathrm{a}$ & $25.47 \pm 2.68 \mathrm{a}$ & $26.59 \pm 0.76 \mathrm{a}$ & $24.69 \pm 1.60 \mathrm{a}$ & $26.33 \pm 0.89 \mathrm{a}$ \\
25 & $21.31 \pm 2.91 \mathrm{c}$ & $24.47 \pm 0.65 \mathrm{bc}$ & $24.89 \pm 0.93 \mathrm{bc}$ & $26.42 \pm 2.59 \mathrm{a}$ & $24.58 \pm 0.43 \mathrm{bc}$ & $25.16 \pm 0.87 \mathrm{ab}$ \\
30 & $23.95 \pm 1.12 \mathrm{c}$ & $26.01 \pm 1.19 \mathrm{ab}$ & $25.42 \pm 0.05 \mathrm{bc}$ & $27.37 \pm 0.62 \mathrm{a}$ & $26.76 \pm 1.13 \mathrm{a}$ & $25.92 \pm 1.11 \mathrm{ab}$ \\
\hline
\end{tabular}

Explanations as in Table 1.

Table 3. Colour analysis b* of blanched carrot in micro-perforated MAP for 30 days of storage

\begin{tabular}{ccccccc}
\hline \multirow{2}{*}{ Days } & \multicolumn{7}{c}{ Treatments } \\
\cline { 2 - 7 } & Control & B & C4 & C8 & D4 & D8 \\
\hline 0 & $21.56 \pm 1.49 \mathrm{a}$ & $21.28 \pm 0.58 \mathrm{a}$ & $21.28 \pm 0.58 \mathrm{ab}$ & $21.28 \pm 0.58 \mathrm{a}$ & $21.28 \pm 0.58 \mathrm{a}$ & $21.28 \pm 0.58 \mathrm{a}$ \\
5 & $23.39 \pm 0.12 \mathrm{a}$ & $22.11 \pm 1.19 \mathrm{~b}$ & $20.41 \pm 0.57 \mathrm{a}$ & $22.21 \pm 1.57 \mathrm{bc}$ & $22.58 \pm 0.08 \mathrm{~b}$ & $22.17 \pm 1.47 \mathrm{~b}$ \\
10 & $24.47 \pm 1.06 \mathrm{a}$ & $23.14 \pm 0.19 \mathrm{~b}$ & $23.68 \pm 0.29 \mathrm{a}$ & $22.69 \pm 0.46 \mathrm{bc}$ & $22.92 \pm 0.28 \mathrm{~b}$ & $23.15 \pm 0.86 \mathrm{~b}$ \\
15 & $25.41 \pm 0.05 \mathrm{a}$ & $22.58 \pm 0.44 \mathrm{c}$ & $23.29 \pm 0.90 \mathrm{~b}$ & $23.14 \pm 0.88 \mathrm{~b}$ & $24.30 \pm 1.07 \mathrm{a}$ & $23.67 \pm 1.58 \mathrm{a}$ \\
20 & $24.71 \pm 0.51 \mathrm{a}$ & $23.90 \pm 0.42 \mathrm{a}$ & $23.98 \pm 0.53 \mathrm{a}$ & $23.66 \pm 0.15 \mathrm{a}$ & $23.50 \pm 0.42 \mathrm{a}$ & $24.47 \pm 1.94 \mathrm{a}$ \\
25 & $26.17 \pm 0.04$ & $25.12 \pm 1.04$ & $24.81 \pm 0.69$ & $24.29 \pm 1.87$ & $23.72 \pm 0.35$ & $24.93 \pm 1.39$ \\
30 & $26.54 \pm 0.195 \mathrm{a}$ & $24.92 \pm 0.42 \mathrm{a}$ & $24.12 \pm 0.18 \mathrm{a}$ & $25.16 \pm 1.37 \mathrm{~b}$ & $25.03 \pm 1.39 \mathrm{c}$ & $25.04 \pm 1.13 \mathrm{a}$ \\
\hline
\end{tabular}

Explanations as in Table 1.

during storage periods of 3-7 years provided that most of the initial activity is destroyed. The authors assert that a peroxidase value of about $1 \times 10^{-2}$ units per gram of sample indicated an acceptable degree of quality. Fig. 8 shows the POD activity of all carrot samples. The POD activity increased until a maximum value of $2.71 \mathrm{U} \mathrm{ml}^{-1}$ was reached for the control and $1.16 \mathrm{U} \mathrm{ml}^{-1}$ for $\mathrm{B} 8$ on day 15 . At day 20, the POD activ- ity reached a maximum value of $1.10 \mathrm{U} \mathrm{ml}^{-1}$ for $\mathrm{C} 8,1.12$ $\mathrm{U} \mathrm{ml}^{-1}$ for $\mathrm{D} 4,1.11 \mathrm{U} \mathrm{ml}^{-1}$ for $\mathrm{D} 8$, and $1.13 \mathrm{U} \mathrm{ml}^{-1}$ for $\mathrm{C} 4$ respectively. The POD activity of $\mathrm{C} 8$ was lower compared to other pretreated micro-perforated packaged samples.

Colour parameters $\mathrm{L}^{*} \mathrm{a} * \mathrm{~b}$ were used to evaluate the effect of the pretreatment and packaging method on the colour of the carrot samples during storage (Tables 1-3). The lightness
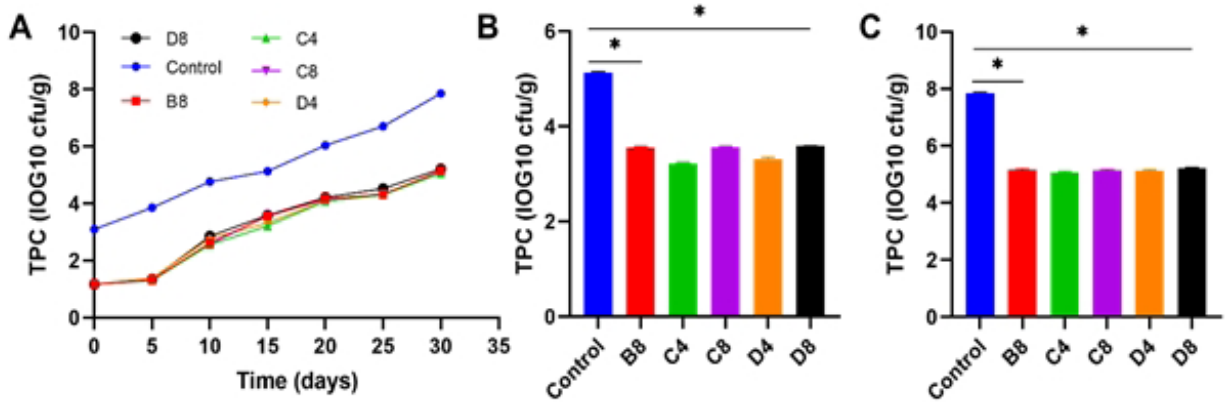

Fig. 9. Effect of blanching and micro-perforated MAP on the total plate count (TPC) of carrot (A) for 30 days of storage, (B) comparative analysis at 15 days and (C) 30 days of storage. 
values $\left(\mathrm{L}^{*}\right)$ of all of the pretreated micro-perforated packaged samples were found to be lower than that of the control sample. (Rawson et al., 2011) reported an increase in the $\mathrm{L}^{*}$ value of carrot as a result of the effect of leaching during hot water blanching, which contrasted with the expected result. In our study, the $\mathrm{L}^{*}$ value of the control sample first increased then decreased with storage time, whereas there was no significant change in the micro-perforated packaged carrot samples. The decrease in $\mathrm{L}^{*}$ value signifies darkening which may be attributed to lignification and surface desiccation. The $\mathrm{a}^{*}$ (redness) and $\mathrm{b}^{*}$ (yellowness) values for both the treated and untreated sample increased as the storage time was prolonged. It has been reported that blanching as a pretreatment prevents non-enzymatic browning, which results in a high value of $\beta$-carotene and total carotenoid content as well as redness and yellowness (Rawson et al., 2011). However, the $a^{*}$ values of the treated micro-perforated packaged samples were higher than those of the control samples, while by contrast, the $b^{*}$ values of the control samples were higher, as an indication of a more intense yellow colour. It may be deduced that colour loss is found to be more significant as the results showed a lower degree of redness and a higher degree of yellowness in the control samples during storage for 30 days. (Gill et al., 2014) carried out research in order to compare the effect of quick freezing and conventional freezing combined with steam blanching and hot water blanching on the colour of carrot. The results showed that hot water blanching alone produced the best result for $\mathrm{a}^{*}$ while hot water combined with quick freezing produced the best result for $\mathrm{L}^{*} \mathrm{a}$ b.

Several published studies have investigated the effect of blanching in eliminating and reducing the microbial load in food products. Also, MAP has proven to be effective in inhibiting the growth of microorganisms. In our study, the microbial count consistently increased in all carrot samples as the storage duration increased. The changes in the total plate count (TPC) for the carrot samples over a 30-day period are shown in Fig. 9. The microbial load in the control samples was higher than those of the pretreated samples in the perforated packaging. This shows that blanching substantially affected the initial microbial load. (Gill et al., 2014) also reported that a lower microbial load in micro-perforated packaged carrot samples occurred as a result of lower oxygen levels and higher carbon dioxide concentrations in perforated packages.

\section{CONCLUSIONS}

1. In this study, it was found that blanching reduced the initial microbial load and improved quality in micro-modified atmosphere packaging.

2. Micro-perforated modified atmosphere packaging for the $\mathrm{C} 8$ samples substantially reduced the degradation of $\beta$-carotene, microbial load, and loss of firmness, decreased water mobility, while the water activity, moisture content and peroxidase increased in the carrot samples during storage as compared to other samples.
3. The results showed that moderate perforation for the duration of cold storage could preserve desirable carrot qualities. This may be a promising preservation technique for carrots and other fresh food products to ensure increased shelf life and retain the quality attributes of the products.

Conflict of interest: The authors declare no conflict of interest.

\section{REFERENCES}

Aindongo W.V., Caleb O.J., Mahajan P.V., Manley M., and Opara U.L., 2014. Effects of storage conditions on transpiration rate of pomegranate aril-sacs and arils. South African J. Plant Soil, 31(1), 7-11, https://doi.org/10.1080/02571862 .2014 .868049

Anthon G.E., and Barrett D.M., 2002. Kinetic parameters for the thermal inactivation of quality-related enzymes in carrots and potatoes. J. Agric. Food Chem., 50(14), 4119-4125, https://doi.org/10.1021/jf011698i

Başkaya Sezer D., and Demirdöven A., 2015. The effects of microwave blanching conditions on carrot slices: optimization and comparison. J.Food Processing Preservation, 39(6), 2188-2196, https://doi.org/10.1111/jfpp. 12463

Bedford C., and Joslyn M., 1939. Enzyme activity in frozen vegetables. Industrial and Engineering Chemistry, 31(6), 751-758, https://doi.org/10.1021/ie50354a025

Begum S., and Brewer M., 2001. Physical, chemical and sensory quality of microwave-blanched snow peas. J. Food Quality, 24(6), 479-493, https://doi.org/10.1111/j.1745-4557.2001. tb00625.x

Beltrán D., Selma M.V., Tudela J.A., and Gil M.I., 2005. Effect of different sanitizers on microbial and sensory quality of freshcut potato strips stored under modified atmosphere or vacuum packaging. Postharvest Biology Technol., 37(1), 37-46, https://doi.org/10.1016/j.postharvbio.2005.02.010

Bhattacharya M., Punathil L., and Basak T., 2017. A theoretical analysis on the effect of containers on the microwave heating of materials. Int. Communications in Heat and Mass Transfer, 82, 145-153, https://doi.org/10.1016/j. icheatmasstransfer.2017.02.010

Bingol G., Wang B., Zhang A., Pan Z., and McHugh T.H., 2014. Comparison of water and infrared blanching methods for processing performance and final product quality of French fries. J. Food Eng., 121, 135-142, https://doi. org/10.1016/j.jfoodeng.2013.08.001

Dawange S.P., Dash S.K., Bal L.M., and Panda M.K., 2016. Quality of minimally processed carrots in perforation-mediated modified-atmosphere packaging (PM-MAP). J. Food Measurement Characterization, 10(4), 746-754, https://doi. org/10.1007/s11694-016-9359-3

Defilippi B.G., Dandekar A.M., and Kader A.A., 2005. Relationship of ethylene biosynthesis to volatile production, related enzymes, and precursor availability in apple peel and flesh tissues. J. Agric. Food Chem., 53(8), 3133-3141, https://doi.org/10.1021/jf047892x

Dutta D., Raychaudhuri U., and Chakraborty R., 2005. Retention of $\beta$-carotene in frozen carrots under varying conditions of temperature and time of storage. Afr. J. Biotechnol., 4(1), 102. 
Ezeanaka M.C., Nsor-Atindana J., and Zhang M., 2019. Online Low-field Nuclear Magnetic Resonance (LF-NMR) and Magnetic Resonance Imaging (MRI) for Food Quality Optimization in Food Processing. Food Bioproc. Tech., 1-17, https://doi.org/10.1007/s11947-019-022 96-w

Fallik E., 2004. Prestorage hot water treatments (immersion, rinsing and brushing). Postharvest Biol. Tec., 32(2), 125-134, https://doi.org/10.1016/j.postharvbio.2003. 10.005

Fan K., Zhang M., Fan D., and Jiang F., 2019. Effect of carbon dots with chitosan coating on microorganisms and storage quality of modified-atmosphere-packaged fresh-cut cucumber. J. Sci. Food Agr., 99(13), 6032-6041, https://doi.org/10. 1002/jsfa.9879

Funamoto Y., Yamauchi N., and Shigyo M., 2003. Involvement of peroxidase in chlorophyll degradation in stored broccoli (Brassica oleracea L.) and inhibition of the activity by heat treatment. Postharvest Biol. Tec., 28(1), 39-46, https://doi. org/10.1016/s0925-5214(02)00143-6

Funamoto Y., Yamauchi N., Shigenaga T., and Shigyo M., 2002. Effects of heat treatment on chlorophyll degrading enzymes in stored broccoli (Brassica oleracea L.). Postharvest Biol. Tec., 24(2), 163-170, https://doi.org/10. 1016/s0925-5214(01)00135-1

Gaggiotti S., Mascini M., Pittia P., Della Pelle F., and Compagnone D., 2019. Headspace Volatile Evaluation of Carrot Samples-Comparison of GC/MS and AuNPshpDNA-Based E-Nose. Foods, 8(8), 293, https://doi.org/10. 3390/foods 8080293

Garcia A., Mount J., and Davidson P., 2003. Ozone and chlorine treatment of minimally processed lettuce. J. Food Sci., 68(9), 2747-2751, https://doi.org/10.1111/j.1365-2621.2003.tb05799.x

Garcia E., and Barrett D.M., 2002. Preservative treatments for fresh-cut fruits and vegetables. Fresh-Cut Fruits and Vegetables, 267-304, https://doi.org/10.1201/9781420031 874.ch9

Gill G.S., Gupta S.K., Mittal T., and Sharma S., 2014. Effect of freezing and blanching on quality traits of carrot (Daucus carota L.). J. Res., 51(3and4), 286-290.

Guerra-Vargas M., Jaramillo-flores M.E., Dorantes-alvarez L., and Hernández-sánchez H., 2001. Carotenoid retention in canned pickled jalapeño peppers and carrots as affected by sodium chloride, acetic acid, and pasteurization. J. Food Sc., 66(4), 620-626, https://doi.org/ 10.1111/j.13652621.2001.tb04611.x

Harris L., Farber J., Beuchat L., Parish M., Suslow T., Garrett E., and Busta F., 2003. Outbreaks associated with fresh produce: incidence, growth, and survival of pathogens in fresh and fresh-cut produce. Compr. Rev. Food Sci. F., 2, 78-141, https://doi.org/10.1111/j.1541-4337.2003.tb00031.x

Hossain M.A., and Gottschalk K., 2009. Effect of moisture content, storage temperature and storage period on colour, ascorbic acid, lycopene and total flavonoids of dried tomato halves. Int. J. Food Sci. Tech., 44(6), 1245-1253, https:// doi.org/10.1111/j.1365-2621. 2009.01954.x

Howard L., and Dewi T., 1996. Minimal processing and edible coating effects on composition and sensory quality of minipeeled carrots. J. Food Sci., 61(3), 643-646, https://doi.org/ 10.1111/j.1365-2621.1996.tb13177.x

Hussein Z., Caleb O.J., and Opara U.L., 2015b. Perforationmediated modified atmosphere packaging of fresh and minimally processed produce -A review. Food Packag. Shelf Life, 6, 7-20, https://doi.org/10.1016/j.fpsl.2015. 08.003
Hussein Z., Caleb O.J., Jacobs K., Manley M., and Opara U.L., 2015a. Effect of perforation-mediated modified atmosphere packaging and storage duration on physicochemical properties and microbial quality of fresh minimally processed 'Acco'pomegranate arils. LWT-Food Sci. Technol., 64(2), 911-918, https://doi.org/10.1016/j.lwt.2015.06.040

Ilić Z.S., Šunić L., Barać S., Stanojević L., Cvetković D., and Marinković D., 2013. Effect of postharvest treatments and storage conditions on quality parameters of carrots. J. Agric. Sci., 5(5), 100-106, https://doi.org/10. 5539/jas.v5n5p100

Irtwange S., 2006. Application of modified atmosphere packaging and related technology in postharvest handling of fresh fruits and vegetables. Agric. Eng. Int.: CIGR J., n.pag.

Jacxsens L., Devlieghere F., Ragaert P., Vanneste E., and Debevere J., 2003. Relation between microbiological quality, metabolite production and sensory quality of equilibrium modified atmosphere packaged fresh-cut produce. Int. J. Food Microbiol., 83(3), 263-280, https://doi.org/10.1016/ s0168-1605(02)00376-8

Jarvis K.L., Evans P.J., Cooling N.A., Vaughan B., Habsuda J., Belcher W.J., . . . Triani G., 2017. Comparing three techniques to determine the water vapour transmission rates of polymers and barrier films. Surf. Interfaces, 9, 182-188, https://doi.org/10.1016/j.surfin.2017.09.009

Kaack K., Nielsen M., Christensen L.P., and ThorupKristensen K., 2001. Nutritionally important chemical constituents and yield of carrot (Daucus carota L.) roots grown organically using ten levels of green manure. Acta Agr. Scand., Section B-Plant Soil Science, 51(3), 125-136, https://doi.org/10.1080/09064710127616

Klaiber R.G., Baur S., Wolf G., Hammes W.P., and Carle R., 2005. Quality of minimally processed carrots as affected by warm water washing and chlorination. Innov. Food Sci. Emerg. Technol., 6(3), 351-362, https://doi.org/10.1016/j. ifset.2005.03.002

Kumar N., Sarkar B., Sharma H., and Jha S.K., 2012. Colour kinetics and storage characteristics of carrot, pulse and rice by-product based extrudates. Br. Food J., https://doi.org/10. 1108/00070701211258826

Lamikanra O., 2002. Enzymatic effects on flavor and texture of fresh-cut fruits and vegetables. Fresh-Cut Fruits and Vegetables: Science, Technology and Market, 125-186, https://doi.org/10.1201/9781420031874.ch6

Larsen H., and Wold A.-B., 2016. Effect of modified atmosphere packaging on sensory quality, chemical parameters and shelf life of carrot roots (Daucus carota L.) stored at chilled and abusive temperatures. Postharvest Biol. Tec., 114, 76-85, https://doi.org/10.1016/j.postharvbio.2015.11.014

Linke M., and Geyer M., 2013. Condensation dynamics in plastic film packaging of fruit and vegetables. J. Food Eng., 116(1), 144-154, https://doi.org/10.1016/j.jfoodeng.2012. 11.026

Mahajan P.V., Caleb O.J., Singh Z., Watkins C.B., and Geyer M., 2014. Postharvest treatments of fresh produce. Philosophical Transactions of the Royal Society A: Mathematical, Phys. Eng. Sci., 372(2017), 20130309, https://doi.org/10.1098/rsta. 2013.0309

Mangaraj S., Goswami T., and Mahajan P., 2009. Applications of plastic films for modified atmosphere packaging of fruits and vegetables: a review. Food Eng. Rev., 1(2), 133-158, https://doi.org/10.1007/s12393-009-9007-3 
Martin-Diana A.B., Rico D., Frias J.M., Barat J., Henehan G., and Barry-Ryan C., 2007. Calcium for extending the shelf life of fresh whole and minimally processed fruits and vegetables: a review. Trends in Food Sci. Technol., 18(4), 210-218, https://doi.org/10.1016/j.tifs.2006.11.027

Martín-Belloso O., Soliva-Fortuny R., Elez-Martínez P., Marsellés-Fontanet A.R., and Vega-Mercado H., 2013. Food Safety Management: Chapter 18. Non-thermal Processing Technologies: Elsevier Inc. Chapters, https:// doi.org/10.1016/b978-0-12-381504-0.00018-4

Morales-Blancas E., Chandia V., and Cisneros-Zevallos L., 2002. Thermal inactivation kinetics of peroxidase and lipoxygenase from broccoli, green asparagus and carrots. J. Food Sci., 67(1), 146-154, https://doi.org/10.1111/j.13652621.2002.tb11375.x

Oms-Oliu G., Martínez R.R.-M., Soliva-Fortuny R., and Martín-Belloso O., 2008. Effect of superatmospheric and low oxygen modified atmospheres on shelf-life extension of fresh-cut melon. Food Control, 19(2), 191-199, https:// doi.org/10.1016/j.foodcont.2007.03.009

Opara L.U., Al-Ani M.R., and Al-Shuaibi Y.S., 2009. Physicochemical properties, vitamin $\mathrm{C}$ content, and antimicrobial properties of pomegranate fruit (Punica granatum L.). Food Bioproc. Tech., 2(3), 315-321, https://doi.org/10.1007/ s11947-008-0095-5

Opara U.L., Al-Ani M.R., and Al-Rahbi N.M., 2012. Effect of fruit ripening stage on physico-chemical properties, nutritional composition and antioxidant components of tomato (Lycopersicum esculentum) cultivars. Food Bioproc. Tech., 5(8), 3236-3243, https://doi.org/10.1007/s11947-011-0693-5

Quarcoo P., and Manu F., 2016. The effect of steam and hot water blanching on some quality attributes of cocoyam leaf. MOJ Food Process Technol., 2(5), 164-168, https://doi.org/ 10.15406/mojfpt.2016.02.00050

Qu P., Zhang M., Fan K., and Guo Z., 2020. Microporous modified atmosphere packaging to extend shelf life of fresh foods: A review. Crit. Rev. Food Sci. Nutr., 1-15, https://doi. org/10.1080/10408398.2020.1811635

Rawson A., Tiwari B., Tuohy M., O'donnell C., and Brunton N., 2011. Effect of ultrasound and blanching pretreatments on polyacetylene and carotenoid content of hot air and freeze dried carrot discs. Ultrason. Sonochem., 18(5), 1172-1179, https://doi.org/10.1016/j.ultsonch.2011. 03.009

Realini C.E., and Marcos B., 2014. Active and intelligent packaging systems for a modern society. Meat Sci., 98(3), 404-419, https://doi.org/10.1016/j.meatsci.2014.06.031

Rodriguez-Aguilera R., and Oliveira J.C., 2009. Review of design engineering methods and applications of active and modified atmosphere packaging systems. Food Eng. Rev., 1(1), 66-83, https://doi.org/10.1007/s12393-009 -9001-9

Ruiz-Ojeda L.M., and Peñas F.J., 2013. Comparison study of conventional hot-water and microwave blanching on quality of green beans. Innov. Food Sci. Emerg. Technol., 20, 191-197, https://doi.org/10.1016/j.ifset. 2013.09.009
Saifullah M., McCullum R., McCluskey A., and Vuong Q., 2019. Effects of different drying methods on extractable phenolic compounds and antioxidant properties from lemon myrtle dried leaves. Heliyon, 5(12), e03044, https://doi. org/10.1016/j.heliyon.2019.e03044

Sandhya V.,Ali S.Z., Grover M., Reddy G., and Venkateswarlu B., 2010. Effect of plant growth promoting Pseudomonas spp. on compatible solutes, antioxidant status and plant growth of maize under drought stress. Plant Growth Regul., 62(1), 21-30, https://doi.org/10.1007/s10725-010-9479-4

Severini C., Giuliani R., De Filippis A., Derossi A., and De Pilli T., 2016. Influence of different blanching methods on colour, ascorbic acid and phenolics content of broccoli. J. Food Sci. Technol., 53(1), 501-510, https://doi.org/10.1007/ s13197-015-1878-0

Siddiqui S.A., 2011. Automotive fuel system leak testing: Google Patents.

Soliva-Fortuny R.C., and Martín-Belloso O., 2003. New advances in extending the shelf-life of fresh-cut fruits: a review. Trends Food Sci. Technol., 14(9), 341-353, https:// doi.org/10.1016/s0924-2244(03)00054-2

Terefe N.S., Buckow R., and Versteeg C., 2014. Quality-related enzymes in fruit and vegetable products: effects of novel food processing technologies, part 1: high-pressure processing. Crit. Rev. Food Sci. Nutr., 54(1), 24-63, https://doi.org/ 10.1080/10408398.2011.566946

Tunde-Akintunde T., 2010. Effect of pretreatment on drying time and quality of chilli pepper. J. Food Process. Pres., 34(4), 595-608, https://doi.org/10.1111/j.1745-4549.2008.00360.x

Wani S.A., and Kumar P., 2018. Fenugreek: A review on its nutraceutical properties and utilization in various food products. J. Saudi Soc. Agric. Sci., 17(2), 97-106, https://doi.org/ 10.1016/j.jssas.2016.01.007

Worth G., Beck M., Jäckle A., and Meyer H., 2002. The MCTDH Package, Version 8.2,(2000). H.D. Meyer, version, 8.

Xiao H.-W., Pan Z., Deng L.-Z., El-Mashad H.M., Yang X.-H., Mujumdar A.S., . . . Zhang Q., 2017. Recent developments and trends in thermal blanching-A comprehensive review. Inf. Process. Agric., 4(2), 101-127, https://doi.org/ 10.1016/j.inpa.2017.02.001

Yam K.L., Takhistov P.T., and Miltz J., 2005. Intelligent packaging: concepts and applications. J. Food Sci., 70(1), R1-R10, https://doi.org/10.1111/j.1365-2621.2005.tb09052.x

Zang X., Zu Y., Zhang T., Xia K., Song Y., Wang Y., .. . Tan M., 2017. Dynamic Water Mobility in Sea Cucumber (Stichopus japonicas) During Drying Process Assessed by LF-NMR and MRI in situ. Int. J. Food Eng., 13(9), https://doi.org/10. 1515/ijfe-2016-0360

Zhang Z., Pang X., Duan X., and Ji Z., 2003. The anthocyanin degradation and anthocyanase activity during the pericarp browning of lychee fruit. Scientia Agricultura Sinica, 36(8), 945-949.

Zhang Z., Pang X., Xuewu D., Ji Z., and Jiang Y., 2005. Role of peroxidase in anthocyanin degradation in litchi fruit pericarp. Food Chem., 90(1-2), 47-52, https://doi.org/10.1016/ j.foodchem.2004.03.023 